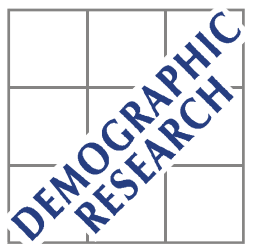

Demographic Research a free, expedited, online journal of peer-reviewed research and commentary in the population sciences published by the Max Planck Institute for Demographic Research Doberaner Strasse 114 D D-18057 Rostock · GERMANY www.demographic-research.org

DEMOGRAPHIC RESEARCH

VOLUME 7, ARTICLE 18, PAGES 593-624

PUBLISHED 17 DECEMBER 2002

www.demographic-research.org/Volumes/Vol7/18/

DOI: $10.4054 /$ DemRes.2002.7.18

Research Article

\title{
Cohabiting unions in France and West Germany: Transitions to first birth and first marriage
}

\section{Jean-Marie Le Goff}

(C) 2002 Max-Planck-Gesellschaft. 


\section{Table of Contents}

1 Introduction $\quad 594$

2 Development of non-marital unions and non- 595

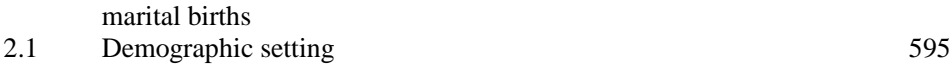

2.1.1 Development of cohabiting unions 595

2.1.2 Differences in non-marital births between France 597 and West Germany

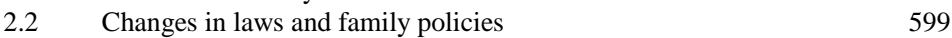

2.2.1 West Germany 600

$\begin{array}{lll}2.2 .2 & \text { France } & 601\end{array}$

$\begin{array}{lll}2.3 .3 & \text { Intermediate Summary } & 602\end{array}$

3. Polarization and pluralization hypotheses 603

$4 \quad$ Event history model to estimate first birth and 604 marriage in cohabiting unions

5 Results 608

5.1 Interrelations between events 608

$\begin{array}{ll}5.2 & \text { Cohort and conception effects on marriage } \\ 5.3 & \text { Coh }\end{array}$

$\begin{array}{ll}5.3 & \text { Cohort and marriage effects in conception } \\ \end{array}$

6 Conclusions 613

$7 \quad$ Acknowledgements $\quad 614$

$\begin{array}{ll}\text { Notes } & 615\end{array}$

$\begin{array}{ll}\text { References } & 617\end{array}$

$\begin{array}{ll}\text { Appendix } & 621\end{array}$ 
Research Article

\title{
Cohabiting unions in France and West Germany:Transitions to first birth and first marriage
}

\author{
Jean-Marie Le Goff ${ }^{1}$
}

\begin{abstract}
This paper compares the non-marital birth pattern in France and West Germany. Since the beginning of the eighties, France witnessed a steady increase in non-marital birth rates, while in West Germany non-marital birth rates have remained at a relatively low level. We attribute these differences to the institutional and legal constraints from both sides of the Rhine which hamper or foster childbearing in cohabiting unions. Using data from the French and German Family and Fertility Survey, we apply event history modeling to the transition to marriage and first birth. Our results indicate a polarization of family forms in both countries. In West Germany, we find a polarization in a "family sector" and a "non-family sector" while in France there is a polarization in a "marriage sector" and a "cohabiting sector".
\end{abstract}

1 Authors' correspondence address: Institute for Life Course and Life Style Studies (PaVie), University of Lausanne, Bâtiment Provence, CH-1015 Lausanne, Switzerland. Email: JeanMarie.LeGoff@pavie.unil.ch. Tel: +41-21 69238 48. Fax: +41-21 6923845. 


\section{Introduction}

The aims of this paper are to develop some hypotheses and present some results on differences in marriages and first births of women living in West Germany and in France. These two neighboring countries present an interesting comparative case study. There have been substantial economic and cultural exchanges between these two countries since the 1950s. Moreover, general changes in demographic trends like the decrease in marriages and fertility and the increase in divorces have followed a similar pattern (Lesthaeghe 1995). Both countries also experienced an increase in cohabiting unions (Kiernan 2001a). Despite these similarities, important "demographic differences" remain. French total fertility rates (TFR) have traditionally been higher, on average by the value 0.3 to 0.7 since 1965 (Council of Europe, 2001). In 1965, the TFR was 2.7 in France and 2.4 in West Germany. In both countries, the TFR decreased drastically until the middle of the seventies and levelled off thereafter. In 1999, the TFR was 1.8 in France and 1.4 in West Germany. Moreover, pronounced differences in nonmarital births between France and West Germany have emerged since the beginning of the eighties. France witnessed a big increase in non-marital fertility rates; from roughly $11 \%$ in 1980 they reached $41 \%$ in 1999. In West Germany, the increase in non-marital births was less pronounced, from $8 \%$ to $18 \%$ (Council of Europe, 2001). In most developed countries, an increase in non-marital births occurred simultaneously with an increase in non-marital unions (Kiernan 2001a and b). France appears to follow this pattern, but West Germany constitutes an exceptional case. In this paper, we focus on differences in non-marital fertility between these two countries, peculiarly on the role that non-marital cohabitation plays.

In section two of this paper, we present some basic statistics on the increase in non-marital unions in the two countries. We then review changes in institutions and family policies of each country with a particular focus on regulations that encourage or discourage non-marital unions. In section three, we develop some hypotheses concerning interrelations between the institutional contexts and demographic behaviors. We argue that the West German institutional context corresponds to a process of polarization of women between a family sector and a non-family sector, while the French institutional context corresponds to a process of pluralization of family formation and situation. In the fourth section, we develop an event history model on the transition to first birth and first marriage for couples in a cohabiting union. We consider both transitions as interrelated processes in which marriage affects first birth and vice versa. In section five, we discuss the results of this model for both countries. Section six contains the concluding remarks. 


\section{Development of non-marital unions and non-marital births}

\subsection{Demographic setting}

In this section, we present some basic indicators on the differences in non-marital unions and non-marital births in West Germany and France. These analyses are based on the "original" national FFS data of each country. The German survey was carried out in 1992 and contains men and women of German nationality born between 1952 and 1972 (Pohl 1995). We restrict our analysis to women who were born in the territories of the former Federal Republic of Germany ("alte Länder"). The French sample contains women and men born between 1944 and 1974 who were living in France in 1994 (INED 1997). We restrict our analysis to women of French nationality in order to harmonize the French sample with the German one.

\subsubsection{Development of cohabiting unions}

Similar to other European countries, France and Germany have witnessed an increase in non-marital unions during the last thirty years. In Table 1, we display women who began a first union with either a marriage or a cohabiting union (Note 1). For the cohorts 1944-1948, about 22 percent of French women started their first union as a cohabiting union. For the cohorts 1964-1968, this applies to 81 percent. Starting a first partnership as a non-marital union seems to be a little less frequent in West Germany. However, as in France, this kind of union formation is becoming more and more prevalent for younger cohorts.

Table 1: $\quad$ Proportion of first unions beginning by a cohabitation by cohort (in \%)

\begin{tabular}{cccccc} 
& France & & \multicolumn{2}{c}{ Germany } \\
\hline Age in 1994 & Cohort & & Age in 1992 & Cohort \\
\hline $46-50$ & $1944-48$ & 22.3 & & & \\
$41-45$ & $1949-53$ & 32.7 & & $52-56$ & 38.3 \\
$36-40$ & $1954-58$ & 44.0 & $36-40$ & $57-61$ & 56.0 \\
$31-35$ & $1959-63$ & 63.6 & $31-35$ & $62-66$ & 67.9 \\
$26-30$ & $1964-68$ & 81.3 & $26-30$ & \\
\hline
\end{tabular}

Sources : PAU-FFS data (Germany: 1992 ; France: 1994)

The increase in non-marital unions can be illustrated from the cohort as well as from the period perspective. Table 2 addresses this aspect by displaying the same statistics by 
calendar time. In both countries, the ratio of unions that begin with a cohabiting "spell" increases over time. At the beginning of the seventies, the "norm" was to start a union with a marriage. At the beginning of the nineties, the vast majority first entered a cohabiting union. However, there are small differences in the general pattern between the two countries (Note 2). Until the 1980s, the proportion of non-marital unions was more prevalent in Germany than in France. Germany witnessed a big increase during the second half of the seventies, while during the eighties the increase was only modest. At the beginning of the nineties, three-quarters of all unions start as a non-marital union. France experienced major changes during the eighties. First partnership starting with a cohabiting "spell" became the most frequent pattern during these years. Marriages represented only one union in nine at the beginning of the nineties.

Table 2: $\quad$ Proportion of first unions beginning by a cohabitation across calendar time (in \%)

\begin{tabular}{ccc} 
Year of union formation & France & West-Germany \\
\hline $1965-69$ & 16.3 & \\
$1970-74$ & 26.2 & 30.8 \\
$1975-79$ & 39.2 & 50.2 \\
$1980-84$ & 65.5 & 57.1 \\
$1985-89$ & 80.4 & 67.2 \\
$1990-1992 / 94$ & 87.8 & 74.5 \\
\hline
\end{tabular}

Sources : PAU-FFS data (Germany: 1992 ; France: 1994)

The high prevalence of cohabitation as the first type of union does not necessarily mean that cohabitation has replaced marriage or that it constitutes an alternative to it. In Table 3 , the role of cohabitation is investigating from a life course perspective. This table displays for each cohort the proportion of women who were single or lived in a nonmarital or marital union at ages 25, 30 and 35 years old. In all cohorts from the two countries, the proportion of married women increases with age and the proportion of singles decreases. The proportion of cohabiting unions is stable over age and, if it increases across cohorts, it is always lower than the proportion of married women. In the majority of cases, cohabitation appears to be a transitory state during the life course before an eventual marriage either with the same or with another partner. In the case of younger French cohorts, it is worth noting that there is a large increase of women who live in non-marital unions at age 25 amounting to 30 percent. A more recent survey than the French FFS, the "family history survey" which was conducted in 1999, shows similar results (Mazuy and Toulemon 2001). 
Table 3: $\quad$ Marital status at 25, 30 and 35 years old, by cohort (in \%)

\begin{tabular}{|c|c|c|c|c|c|c|c|c|c|c|}
\hline & & \multicolumn{3}{|c|}{25 years } & \multicolumn{3}{|c|}{30 years } & \multicolumn{3}{|c|}{35 years } \\
\hline & & Single & $\begin{array}{l}\text { Coha- } \\
\text { biting }\end{array}$ & Married & Single & $\begin{array}{l}\text { Coha- } \\
\text { biting }\end{array}$ & Married & Single & $\begin{array}{l}\text { Coha- } \\
\text { biting }\end{array}$ & Married \\
\hline & Cohort & & & & & & & & & \\
\hline \multirow[t]{5}{*}{ France } & $1944-48$ & 22.7 & 4.3 & 72.9 & 13.4 & 5.7 & 80.9 & 14.6 & 3.7 & 81.6 \\
\hline & $1949-53$ & 23.4 & 6.3 & 70.3 & 16.9 & 4.8 & 78.2 & 16.5 & 5.8 & 77.6 \\
\hline & $1954-58$ & 24.0 & 10.6 & 65.4 & 18.7 & 11.1 & 70.1 & 18.3 & 10.3 & 71.3 \\
\hline & $1959-63$ & 33.9 & 17.1 & 49.0 & 24.6 & 20.8 & 54.6 & & & \\
\hline & $1964-68$ & 34.2 & 32.8 & 33.0 & & & & & & \\
\hline \multirow{3}{*}{$\begin{array}{l}\text { West } \\
\text { Germany }\end{array}$} & $1952-56$ & 28.1 & 12.3 & 59.6 & 15.3 & 9.5 & 75.2 & 14.0 & 11.1 & 74.9 \\
\hline & $1957-61$ & 29.2 & 15.3 & 55.5 & 20.2 & 14.3 & 65.5 & & & \\
\hline & $1962-66$ & 42.8 & 19.9 & 37.3 & & & & & & \\
\hline
\end{tabular}

Sources : PAU-FFS data (Germany: 1992 ; France: 1994)

\subsubsection{Differences in non-marital births between France and West Germany}

Until the end of the seventies, the level of non-marital births was very similar in France and in West Germany (Figure 1). Less than $10 \%$ of the total births were out-of-wedlock until 1978 in both countries. Non-marital births increased strongly in France during the eighties, the proportion of non-marital births among all births reached $30 \%$ and $40 \%$ at the beginning and the end of the nineties repectively. The non-marital birth rate in Germany does not show such a large increase between 1980 and 1998. It rose from 8\% in 1980 to $14.3 \%$ in 1997. At the end of the nineties, the non-marital birth rate appears to increase a little more strongly and reached $17.6 \%$ in 1999. 
Figure 1: $\quad$ Percent of non-marital births among all births between 1960 and 1999

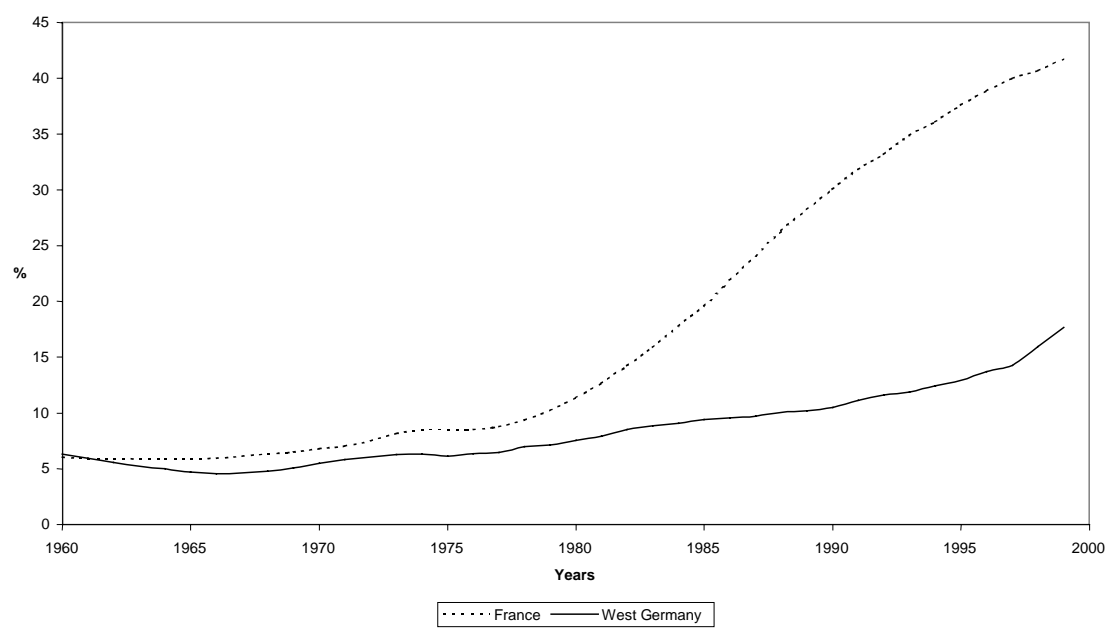

Source : Council of Europe (2001)

The simultaneous increase in cohabiting unions and non-marital births suggests that a lot of non-marital births are births to women living in a cohabiting union. In order to address this aspect, we proceeded as follows. On the basis of the FFS data, we calculated the percentage of women who (1) had the first birth as single mothers, (2) lived in a cohabiting union at first birth, (3) married between the conception and the first birth and (4) married before the first conception.

As can be inferred from Table 4 (Note 3), in France the increase in non-marital first births for the most recent cohorts corresponds to a decrease in women who marry between the conception and the birth of a child (Toulemon 1995 and 1997). It corresponds also to a decline in the proportion of women who get married before the conception of the first child. On the other hand, the increase in the proportion of nonmarital births outside of a union is only modest.

In Germany, the proportion of first births in non-marital unions is bigger for the cohort of women born between 1957 and 1961 in comparison with the previous cohort, but this increase appears to be lower than in France. It corresponds with a decrease in first births for women without partners. It should be noted that in the most recent cohort, the proportion of non-marital conceptions followed by a marriage increases in 
comparison with the previous cohort (category 3). A decrease of conceptions in marital unions corresponds to this increase (category 4).

Table 4: $\quad$ First birth by the marital status of the woman

\begin{tabular}{|c|c|c|c|c|c|c|c|c|}
\hline & \multicolumn{5}{|c|}{ France } & \multicolumn{3}{|c|}{ West Germany } \\
\hline $\begin{array}{l}\text { Cohorts } \\
\text { (Age at moment of survey) }\end{array}$ & $\begin{array}{c}44-48 \\
(46-50)\end{array}$ & $\begin{array}{c}49-53 \\
(41-45)\end{array}$ & $\begin{array}{c}54-58 \\
(36-35)\end{array}$ & $\begin{array}{l}59-63 \\
(31-35)\end{array}$ & $\begin{array}{c}64-69 \\
(26-30)\end{array}$ & $\begin{array}{c}52-56 \\
(36-40)\end{array}$ & $\begin{array}{c}57-61 \\
(31-35)\end{array}$ & $\begin{array}{c}62-66 \\
(26-30)\end{array}$ \\
\hline $\begin{array}{l}\text { (1) Lone parenthood at first } \\
\text { birth }\end{array}$ & 11.2 & 5.9 & 6.6 & 9.5 & 9.4 & 11.0 & 6.7 & 9.2 \\
\hline $\begin{array}{l}\text { (2) Cohabitation at first } \\
\text { birth }\end{array}$ & 2.5 & 5.9 & 8.9 & 17.8 & 27.7 & 7.1 & 12.7 & 17.5 \\
\hline $\begin{array}{l}\text { (3) Marriage between } \\
\text { conception and first birth }\end{array}$ & 22.4 & 23.6 & 21.9 & 13.0 & 10.6 & 24.2 & 12.4 & 30.1 \\
\hline $\begin{array}{l}\text { (4) Marriage before } \\
\text { conception and first birth }\end{array}$ & 64.0 & 64.5 & 62.6 & 59.7 & 52.3 & 57.4 & 63.2 & 43.2 \\
\hline $\mathrm{N}$ & 363 & 437 & 397 & 355 & 229 & 308 & 354 & 260 \\
\hline
\end{tabular}

Sources : PAU-FFS data (Germany: 1992 ; France: 1994)

The increase in cohabiting unions prompted policy makers and legislators in most developed countries to introduce amendments in the domain of family and filiation laws (Prioux 1994, Bradley 2001). An overview of changes in family policies and laws on both sides of the Rhine is presented in the next section.

\subsection{Changes in laws and family policies}

During the beginning of the $\mathrm{XX}^{\text {th }}$ century, cohabiting unions were, at best, considered outside of the law and ignored by authorities or, at worst, forbidden and prosecuted by justice (Bradley 2001). Most of the countries had adopted devices of family regulation based on the model of conjugal family and legitimate births. These family regulations remained unchanged until the end of the sixties. In the current context, cohabiting unions and out-of-wedlock births raise important juridical questions (Théry 1998). Firstly, the relationship between the two partners (horizontal link) has to be clarified. For example, questions about mutual support and inheritance issues have to be resolved. Secondly, the relationship between the unmarried father and the child (vertical link) has to be specified, i.e. the parental authority and the recognition of the child by the unmarried father have to be clarified. As mentioned by several authors, new measures and regulations (and also possibly discussions in the state institution before a rejection of proposal of new measures) depend of legal and cultural traditions and 
family ideologies specific to each country (Gauthier 1996, Hantrais 1997, Eriksen and Lindsay 1999, Bradley 2001).

In West Germany as well as in France, the family is recognized by the state as an institution which plays a role for social cohesion (Fagnani 2001). The two countries, however, display different general and cultural political contexts in the regulation of family forms. There are traditional connections between family and pronatalistic policies in the case of France. Regulation of the family in Germany has been, since the constitution of the Federal Republic of Germany, strongly based on the normative model of conjugal family with the male as breadwinner (Heeren 1982, Schultheis, 1993 and 1999, Gauthier 1996, Vielle 2001). We now spell these issues.

\subsubsection{West Germany}

Article 6 of the German Constitution (1949) stipulates that marriage and the family come under the special protection of the state. According to Stintzing (1999), this entails that both institutions must be protected from state interference but also that the state must promote family and marriage through, for example, its social security scheme or taxation rules. Taxation and the rule of income splitting between the spouses (Ehegattensplitting) offers fiscal advantages for married couples (both with or without children), while cohabiting couples have to file their tax returns separately. This normative representation of family life based on the conjugal family is accompanied by a privatist conception of child education monopolized by families (Vielle 2001). A low availability of childcare scarcely allows women to combine family and professional lives, especially when they have children less than three years of age (Kreyenfeld and Hank 2000, Fagnani 2001).

According to Ostner (2001 p. 99), article 6 of the German Constitution also means, in the context of an increase in cohabiting unions, that "personal relationships which resemble marriage but are not marriage should not be treated better than marriage". Although cohabiting unions and non-marital partnerships marriage are not considered equal to marriages, they are still taken into account in social law and jurisprudence. In 1957, legislation introduced the notion of "marriage-like relationship" (Eheähnlich) in the rules of unemployment benefits (Note 4) (Ostner 2001). This marriage-like relationship was defined in 1958 by the German Constitutional Court as a community of two persons who lived together and shared resources.

The notion of an illegitimate child as it relates to fatherhood also underwent some changes, but not until the 1998 (Stintzing 1999). Parental authority was not given to a father who was not married to the child's mother. He was also denied the right to educate and care for the child. This aspect had several implications like, for example, it was not possible for him to consent to an urgent operation on the child or to represent 
the interests of his child in a council of school (Schultheis 1996, Stintzing 1999). However, in 1991 (Note 5), the Constitutional Court indicated that an unmarried father was allowed to educate and care for the child. Considerations taken into account by the Court included not only the situation of the father, but also the situation of the nonmarital child, who should have been given the same opportunities as marital children when he grows up (Stintzing 1999). In 1998, an amendment to the parental and custody legislation put effectively between legitimate and illegitimate children on an equal basis. Differences in inheritance rights have been abolished and father's rights in connection with illegitimate children have been improved. However, the father is not automatically given the right to custody; instead, both parents have to file a joint declaration to achieve it.

\subsubsection{France}

According to Schultheis (1993 and 1999), French family policies could be characterized by normative neutrality and flexible representations about family lives in contrast with the norm of the conjugal family in German family policies. This conclusion is based on a comparison of each domain of family policy between the countries at the beginning of the nineties. For example, France is characterized by a great availability of childcare, which allows women to combine a professional career with family life. Another example is taxation and the rule of family splitting which offer advantages to couples with children, whether they are married or not (Note 6). The general idea supported by the author is that, in contrast to Germany, France introduced equal treatment of married and unmarried couples in its legislation. However, a historical perspective about the evolution of legislation and laws on cohabiting unions and filiation provides a more ambiguous picture (Martin and Théry 2001).

After the Second World War, French family policies were, as in West Germany, based on the norm of the conjugal family. The increase in cohabiting unions during the last decades did not prompt authorities until 1998 to extend social legislation from married to unmarried couples. Rules of taxation did not allow unmarried couples to jointly declare their income. There were no rights of mutual inheritance in case of the death of a partner. Nevertheless, cohabiting persons were still treated differently than singles, e.g. they were not entitled to claim special allowances, like allowance for family support to lone mothers or allowance for widowhood. The creation of the "Pacte Civil de Solidarité" (PACS) in 1998 partly changed this situation, but did not give the same advantages to cohabiting and married couples (Bradley 2001, Martin and Théry 2001). Despite the increase in cohabiting unions, the French legislation gives its preference to marriage, in a similar manner to the German legislation. 
The situation of illegitimate children and unmarried fathers became a greater concern during the seventies and eighties. It should be mentioned, however, that already before this period, the notion of the legitimate child was replaced in 1946 by the notion of the "dependent child" (Note 7) in the legislation of family allowances (Shultheis 1993). When cohabitation increased at the end of the sixties, new legislation introduced the obligation for a non-married father (cohabiting or not) to recognize his child. However, in this first reform, the parental authority was only given to the mother (Martin and Théry 2001). A new article in the civil code introduced in 1972 the principle of equality between legitimate and illegitimate child. This reform allowed an illegitimate child to inherit its father (but only half of the inheritance the child would receive if the child were legitimate). It should be noted that these reforms were adopted before the increase in out-of-wedlock births. The principal motivation behind their implementation was to allow illegitimate children to have similar rights to those of legitimate children. However, in the context of the increase in non-marital births during the eighties and nineties, a second reform introduced the possibility of joint parental authority for couples who were not married to each other (1987 and 1993), but only if parents were living together and when the father recognized his child.

\subsubsection{Intermediate summary}

In West Germany as well as in France, recent changes in the legislation have granted more rights to couples living in non-marital unions. Cohabiting unions are considered less and less as being "outside the law", but in neither country do cohabiting couples experience such beneficial treatment as in marriage. In both countries, the "normative family model" is still the marital union.

French legislators improved the status of non-marital children earlier than German legislators and a father is now urged to recognize his child. Unlike in Germany, new rules on recognition of children by fathers have preceded the rise in out-of-wedlock births in France. According to Martin and Théry (2001), one illegitimate child in five was recognized during the seventies at the moment of the birth, one in two during the eighties and three in four in 1996. Only six per cent of non-marital children were never recognized by their fathers in 1996. Rules on recognition and parental authority allow cohabiting French couples to have children who have almost the same rights as legitimate children. It was also during this period that women's participation in the labor market increased rapidly. This increase was accompanied by an expansion in childcare facilities, which means that family policies progressively adopted the "working mother model" (Fagnani 2001).

In Germany, in the absence of legislation regarding the recognition and parental authority for a father of a non-marital child until 1998, a pregnancy implied the moral 
obligation for unmarried couples to get married (Dienel 1996). This moral obligation refers not only to the filiation link but also to the link between partners since, in the absence of childcare, numerous women leave their jobs when they become mothers (Note 8). In contrast to France, Germany has retained the normative social representation of the family as a conjugal family with a male breadwinner in its family policies.

\section{Polarization and pluralization hypotheses}

In France as well as in West Germany, the increase in cohabiting unions has been regarded as a sign of a rise of individualization and equality between men and women (Martin and Théry 2001, Ostner 2001). This increase in individualism was associated with the notion of pluralization of family formation and situations. In Germany, the term "family" was substituted by "living forms" (Lebensformen), in order to emphasize that "marriage and marriage-based families have become in this context eligible living forms among many others" (Ostner 2001 p. 92). In a similar manner, the term "family" was progressively replaced by French social scientists during the eighties by its plural, "families", in order to underline the notion of pluralization in family life (Martin and Théry 2001).

However, the idea of a pluralization of family arrangements met with criticism in Germany during the nineties and was contrasted with a "polarization hypothesis" (Strohmeier 1993, Huinink 2001, Ostner 2001). The term is used in various contexts, but in a general manner, it designates a process of differentiation into two dominant groups of couples. The first group is composed of couples who marry and have children. This group of couples forms a "family sector". The second group is composed

of couples who neither marry nor have children. This group then forms a "non-family sector". This non-family sector consists for example of singles or dual career couples without children (Ostner 2001).

In France, the idea of a pluralization in family arrangements met less skepticism as in West Germany; criticism were more about its social meanings and its social consequences (Martin and Théry 2001). For example, it was considered that this process of individualization, in the process of emancipation, is not equally accessible between social groups. Furthermore, the term of pluralization is not limited to describe a plurality in family arrangments. It could also be used to describe the different configurations of couple and family life during the life course (Théry 1998). In the context of a more liberal legislation on filiation than in Germany, marriage is less and less considered as a "founding event" and more and more seen as a non-necessary step during the family life (Kaufmann, 1993). 
The hypotheses of a polarization between a family sector and a non-family sector in West Germany and of a pluralization of family formation and situations in France will serve as a theoretical background to analyze the conception of the first child and marriage. However, as our analysis will be restricted to women who have begun a consensual union, we need to specify these two notions of polarization and pluralization further. From the life course perspective, the polarization in West Germany means that there is a stage during which cohabiting couples branch off into the "marriage sector" (marriage and parenthood) or remain unmarried and childless. In this case, women who have high risks of marrying also encounter high risks of giving birth. In contrast, women who have low risks of marrying also have low risks of giving birth. In other words, we assume that marriage and first births are strongly interrelated in the German institutional framework.

Contrary to Germany, the rise in non-marital births in France suggests that there is no strong interrelation between marriage and parenthood. However, several factors could contradict this hypothesis. First, we have to take into account in the French FFS data that several unions began before the increase in nonmarital births. Marriage and first births could therefore be interrelated in the older cohort of French women. Second, couples who did not marry before or during the pregnancy could marry subsequently for reasons related to advantages of marriage (inheritance rules in case of the decease of one partner, for example). Third, some authors have mentioned that for most traditional couples, marriage remains important, especially as concerns its link with children and family planning (Théry 1998). Eurobarometers data of 1993 show that $46.3 \%$ of French respondents stated the opinion that to "get married is the best way to guarantee the rights of children" (Malpas and Lambert 1993). This is roughly the same as in West Germany where $52 \%$ responded in a similar manner.

\section{Event history model to estimate first birth and marriage in cohabiting unions}

In this methodological section, we present the event history model we will estimate in order to analyze first births and marriages of cohabitant women in France and Germany who did not have children and were not previously married before the beginning of the union (Note 9). Note however that not only the first cohabiting union is taken into account but all cohabiting unions which precede the first marriage. We are particularly interested in the following three aspects:

- First, we want to analyze the effect of the first conception on the marriage transition rate and the effect of marriage on the first birth transition. The questions we 
have are associated with the positive or negative effects of the "disruptive event" on the rate of the analyzed event (for example, if a first conception is accompanied by an increase or a decrease in the marriage rate) in both the short and the long term (Courgeau and Lelièvre 1989, Blossfeld and Rohwer 1995, Blossfeld and Mills 2001);

- Secondly, we seek to understand the development of these two effects over cohorts. We are especially interested to capture the mechanics that have triggered the increase in non-marital births in France;

- Thirdly, we wish to analyze both events as interrelated processes in order to show if observed and unobserved individual characteristics simultaneously influence first birth and first marriage (Brien, Lillard and Waite 1999, Baizán Aassve and Billari 2001 and 2002).

The general principle of the model can be symbolized by the following scheme:

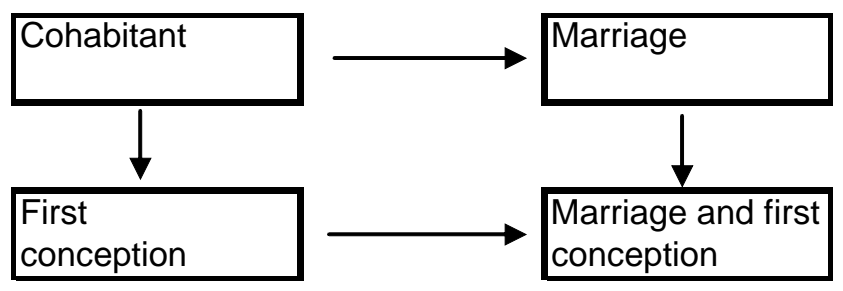

We distinguish women according to whether (1) they have a conception before a marriage, (2) marry before any conception, or whether (3) they do not experience any of these event. Whatever the first event is, it is considered to have a possible impact on the occurrence of the second event. The statistical model is based on simultaneous equations of hazard rates for each event:

$$
\begin{aligned}
& \ln h_{i}^{m}(t)=y^{m}(t)+\sum_{j=1}^{F} \alpha_{j}^{m} x_{i j}+\sum_{j=1}^{V} \beta_{j}^{m} w_{i j}(t)+z_{i}^{m}\left(t+d_{i}\right)+\sum_{k=1,2} g_{k}^{m}\left(t-u_{i}\right) I\left(C_{i}=k\right)+U_{i} \\
& \ln h_{i}^{c}(t)=y^{c}(t)+\sum_{j=1}^{F} \alpha_{j}^{c} x_{i j}+\sum_{j=1}^{V} \beta_{j}^{c} w_{i j}(t)+z_{i}^{c}\left(t+d_{i}\right)+\sum_{k=1,2} g_{k}^{c}\left(t-u_{i}\right) I\left(C_{i}=k\right)+V_{i}
\end{aligned}
$$


The superscripts $m$ and $c$ respectively denote entering marriage and the conception of the first child. The subscript i represents an individual i. $\ln h_{i}^{m}(t)$ and $\ln h_{i}^{c}(t)$ are respectively the hazard rate logarithm of marriage and first conception associated with this individual at the instant $t$, which is time since union formation.

Each $y(t)$ denotes a piecewise linear spline that captures the effect of the duration since the beginning of the union on the intensity of one process. The $x_{i j}(j=1, \ldots, \mathrm{F})$ represent fixed covariates associated with the individual i. It is here important to note that one of these fixed covariates is the birth cohort $C$ of the woman (differentiation between women born between 1952 and 1961 and women born between 1962 and 1972 in the case of West Germany, 1974 in the case of France). The $w_{i j}(j=1, \ldots, \mathrm{V})$ denote time-varying covariates. Each $z_{i}\left(t+d_{i}\right)$ captures the effect of the woman current age on the intensity: $d_{i}$ is here the woman's age at the union formation. The $g\left(t-u_{i}\right)$ are conditional spline effects of covariates that are continuous functions of $t$ from an origin $u_{i}$ (if $\mathrm{t}<u_{i}$, then $g\left(t-u_{i}\right)$ is equal to 0 ). In the case of the marriage process, this spline represents the effect of duration since conception, provided that conception occurred before marriage (for the "conception equation", the spline represents the effect of duration since the marriage). In the present case, we will distinguish one spline for each cohort. Doing so, we assume that the effect of a conception on the process of marriage is different across cohorts. This interaction effect is expressed by $g_{k}{ }^{m}\left(t-u_{i}\right) * I\left(C_{i}=k\right)$ where $\mathrm{I}($.$) is an indicator function equal to 1$ or 0 according to whether or not the individual $i$ belongs to the cohort $k(k=1,2)$. The same assumption is made in the case of the effect of marriage on the process of first conception.

$U_{i}$ and $V_{i}$ denote unobserved heterogeneity components respectively for the processes of marriage and of conception. Each of these terms relates the effect of unobserved characteristics of women. These unobserved characteristics could be, for example, the social group in which they behind. They could also be their values about family and children. The unobserved heterogeneity components are assumed to have a joint bivariate normal distribution with a correlation between them:

$$
\left(\begin{array}{l}
U \\
V
\end{array}\right) \sim N\left(\left(\begin{array}{l}
0 \\
0
\end{array}\right) \cdot\left(\begin{array}{cc}
\sigma_{U}^{2} & \rho_{U V} \cdot \sigma_{U} \sigma_{V} \\
\rho_{U V} \cdot \sigma_{U} \sigma_{V} & \sigma_{V}^{2}
\end{array}\right)\right)
$$


in which $\sigma_{U}^{2}$ and $\sigma_{V}^{2}$ are variances of each unobserved heterogeneity term, $\sigma_{U} \sigma_{V}$ is their covariance and $\rho_{U V}$ is the correlation between the two terms. In the present case, according to our hypotheses on interrelations between marriage and first birth (see section 3), it is expected that this correlation will be positive and strong in the case of West Germany, and less strong, indeed even possibly non important in the case of France.

Data used are, as mentioned in the first part of this paper, original FFS data from West Germany and France (cf. supra). In the case of France, we restrict the sample to women born in 1952 or later in order to have harmonized data with West Germany. We select all unions that begin as non-marital unions. However, we omit cohabiting unions that started after a first conception or that began after a dissolved marriage. For some respondents, we might observe several unions, provided that the union started before the first pregnancy or the first marriage. The date of conception corresponds to the date of the first childbirth minus nine months. Cases are censored at the date of the interview or at the dissolution of the union if that occurred before the interview. For the marriage process, we also censor cases at the date of the interview, at the date of any union dissolution, or at the date of the second child conception if it occurs before the marriage.

Three fixed covariates will be taken into account. The first is the cohort, which we assume plays a crucial role for our analysis (cf. supra). A second covariate is the distinction between first and higher union. The third fixed covariate is a binary variable for whether the parent's respondents were divorced when the respondent reached age 15.

The first time varying covariate is an indicator variable for whether a woman is enrolled in education (school or vocation) or not enrolled in education. The second time varying covariate is the level of education. Since the system of education and vocation differ greatly between France and Germany, we distinguish for each country three levels of education with a scale of comparison inspired and simplified from the scale proposed by Mary et al. (1998). The lower level corresponds to compulsory school. The second level is secondary school; in the case of Germany, this includes an apprenticeship and "Abitur" and in the case of France, this includes a professional certificate, diploma and "baccaulaureat". The higher level corresponds to university, in the case of France including the "Grandes Ecoles".

According to the fact that German data contains a lot of missing values, especially regarding the dates of union formation, the number of unions taken into account for our analysis are 941 for West Germany and 1147 for France (Note 10). 


\section{Results}

The model was estimated using the software aML version 1.04 (Lillard and Panis 2000). Complete results for each event are presented in the table in the appendix. Two models are reported in this table. The first one does not include the unobserved heterogeneity components and the second one does. Comments will refer to the results of the second model. In this second model, variance of both processes was not fixed. In this section, we will comment only the most important results, which are referred to the interrelations between marriage and conception.

\subsection{Interrelations between events}

We expected that the first birth and marriage were strongly interrelated in Germany and less interrelated or not linked in the case of France. These hypotheses seem to be verified. The coefficient of correlation has a value of 0.55 and is significant in the case of West Germany (Table 5). Women who are most likely to have a first birth for unobserved reasons or characteristics are also those who most likely get married. This result also means, however, that women who are less likely to have a first birth are also less likely to get married. This result seems to confirm the general hypothesis of a polarization between a non-family sector (where women do not get married and do not have children) and a family sector in which cohabiting unions become conjugal unions with children. For France, the coefficient of correlation is only 0.36 and is not significant. Marriage and first birth appear to be less interrelated (Note 11). Women who are most likely to bear a first child are not necessarily women who get married other things equal. In the context of a strong increase in non-marital births, marriage appears to be disconnected with conception (Note 12).

Table 5: $\quad$ Unobserved heterogeneity. Standard deviation and correlation

\begin{tabular}{ccc} 
& Germany & France \\
\hline Marriage $\left(\mathrm{U}_{\mathrm{i}}\right)$ & $2.03^{* * *}$ & $0.55^{*}$ \\
Conception $\left(\mathrm{V}_{\mathrm{i}}\right)$ & $0.97^{* *}$ & $1.45^{* * *}$ \\
Correlation & $0.55^{* *}$ & 0.36 \\
\hline
\end{tabular}

Significance: ${ }^{*}=10 \% ;{ }^{* *}=5 \% ;{ }^{* \star *}=1 \%$ 


\subsection{Cohort and conception effects on marriage}

In order to investigate differences in the effect of a conception between old and young cohorts in both countries, we develop a hypothetical example in which a woman forms a consensual union at age 25 and becomes pregnant two years later. Figures 2 and 3 show, respectively for West Germany and France, the effect of a pregnancy in each cohort on the intensity of marriage in comparison with women who do not get pregnant (time scale is the union duration). In both countries, the marriage intensity in the youngest cohort is lower than in the oldest cohort as long as no pregnancies occur (cf. also table in appendix). Each cohort of both countries displays a spike in marriage intensities at the beginning of a pregnancy. The spikes are very similar in both German cohorts during the beginning of the pregnancy. In the case of the oldest cohort, the intensity of marriage decreases during the second half of pregnancy and during the child's first year. After three years of union, marriage rates of mothers become lower than the intensity of marriage of women who did not get pregnant. Women who did not get married during their pregnancy or just after remain unmarried. The decrease in the intensity of marriage at the end of the pregnancy and during the child's first years is lower in the case of the youngest cohort. This youngest cohort then displays the following pattern: as long as women are not pregnant, they get married less often than the oldest cohort does. However, in case of a pregnancy, marriages become more frequent. This suggests that the interrelation between first birth and first marriage has increased over the cohorts.

The development in marriage intensities between the oldest and the youngest cohort played out differently on the other side of the Rhine. Differences in the marriage intensities between both cohorts remain after the birth of the first child. It is only during the second half of the pregnancy that the marriage intensity is lower in the youngest cohort. Moreover, marriage becomes less frequent during the child's first years in both cohorts in comparison with women who did not conceive their first child. This means that women who have a child outside marriage remain unmarried in a similar way as was observed in the oldest cohort of Germany. This last result raises a question about the meaning of marriage for women who did not first get pregnant. 
Figure 2: $\quad$ Effect of pregnancy on marriage intensity (Germany)

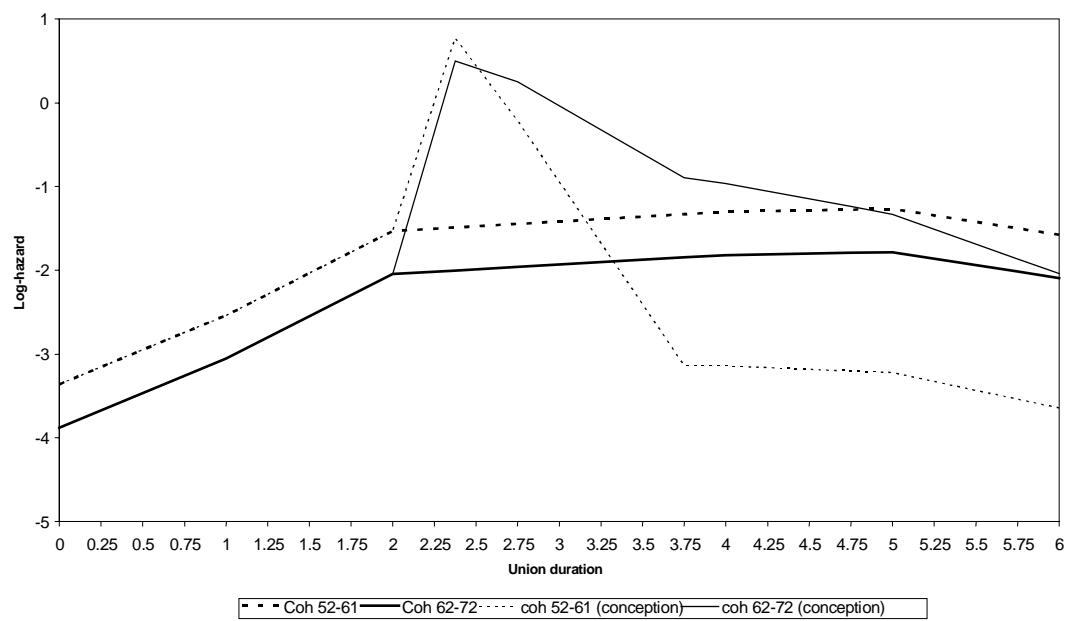

Figure 3: $\quad$ Effect of pregnancy on marriage intensity (France)

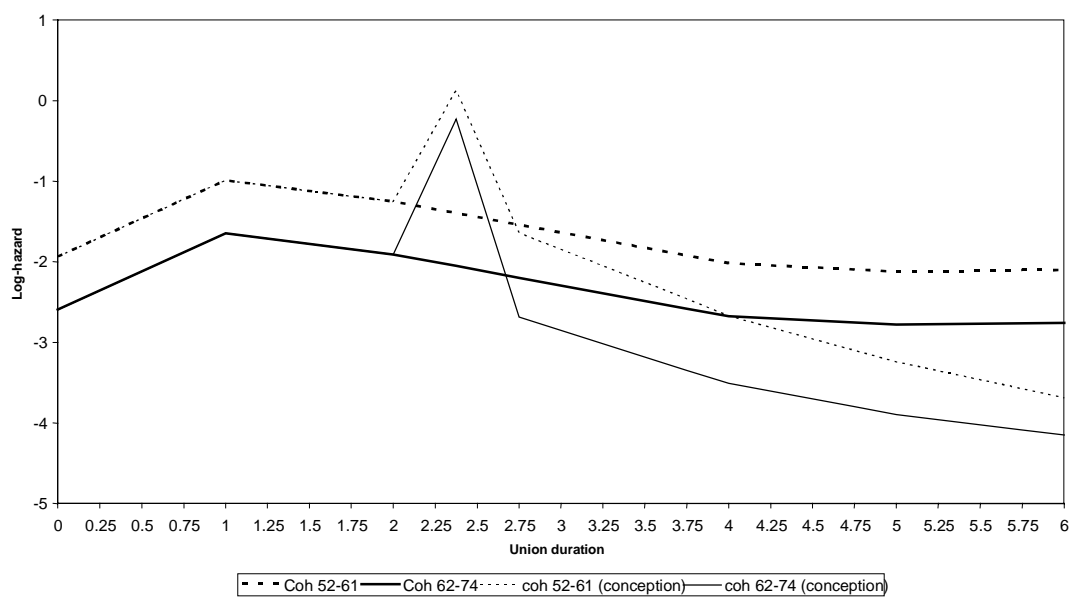




\subsection{Cohort and marriage effects on conception}

In a similar way as in the preceding section (part 5.2), we develop here a hypothetical example in which a non-pregnant and childless woman gets married after two years of living together with her partner (Figures 4 and 5). There is no difference in the conception intensities between cohorts from both sides of the Rhine as long as women do not get married. Such a result in the case of France is surprising at first glance. It indicates, however, that the increase in non-marital births in this country depends only on the decrease of marriage before or during a pregnancy.

The effect of marriage on conception risks is low in Germany in both cohorts (Note 13). In the case of the oldest cohort, the difference in conception intensities between non-married and married women seems to slightly increase over time. However, in the youngest cohort, conception intensities decrease after the first marriage anniversary. After two years of being married, they even drop below the conception intensities of cohabiting couples. A difference between the cohorts then shows a process of differentiation between two groups of married women: those who will get pregnant, usually some time after marriage, and those who remain childless. This last kind of marriage could be motivated by the economic benefits that married couples can take advantage of. In this case, marriage does not mean a bifurcation towards the family sector.

In France, marriage has a bigger effect on conception. The intercept coefficients are significant here. Just after marriage, conception risks are higher in the older than in the younger cohort. But the increase in conception intensities during the first year of marriage is higher in the younger than in the older cohort. After one year of marriage, conception intensities seem similar in both cohorts and the disparity between married and unmarried women appears to be stable.

Results on the effect of a conception on the marriage formation risks, of a marriage on the conception risks and the development of these effects over cohorts indicate that our hypothesis of pluralization in the case of France was not very sufficiently specified. The results in fact show a process of differentiation between two groups of women. The first group contains women who get married before they bear their first child. We can suppose that these women belong to a more or less traditional milieu and that the union they form with their partner is a classical conjugal union, possibly with a male breadwinner. The second group is composed of women who become pregnant while they are unmarried. This process of differentiation between the two groups could be seen as a process of polarization but with a different meaning than in West Germany. Instead of a polarization between a "family sector" and a "non-family sector", this one consists in a process of polarization between a "marriage sector" and a "cohabiting sector". 
Figure 4: $\quad$ Effect of marriage on conception intensity (Germany)

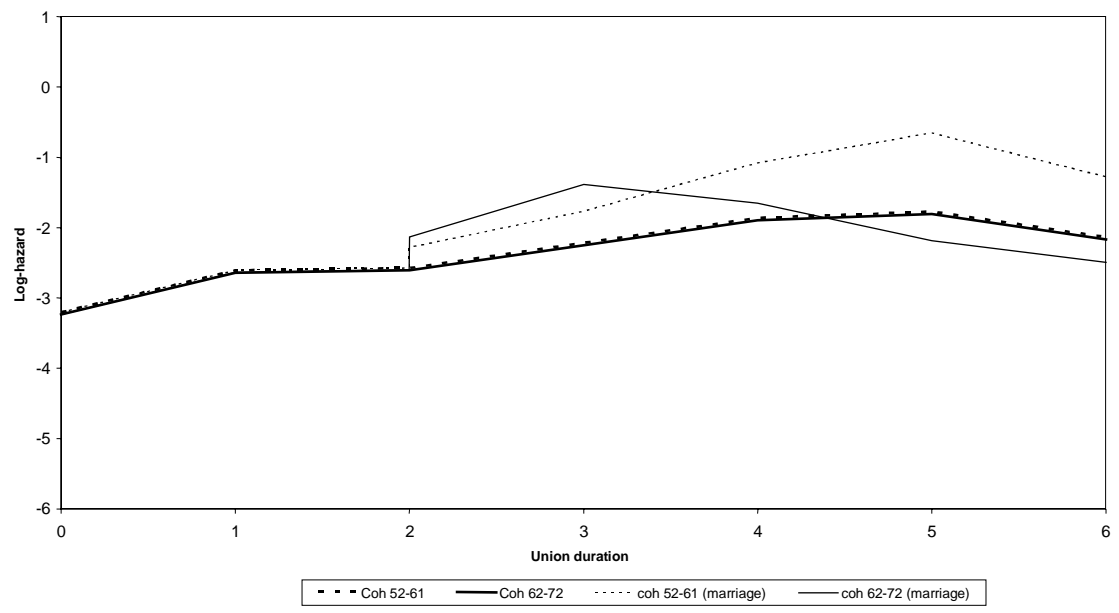

Figure 5: $\quad$ Effect of marriage on conception intensity (France)

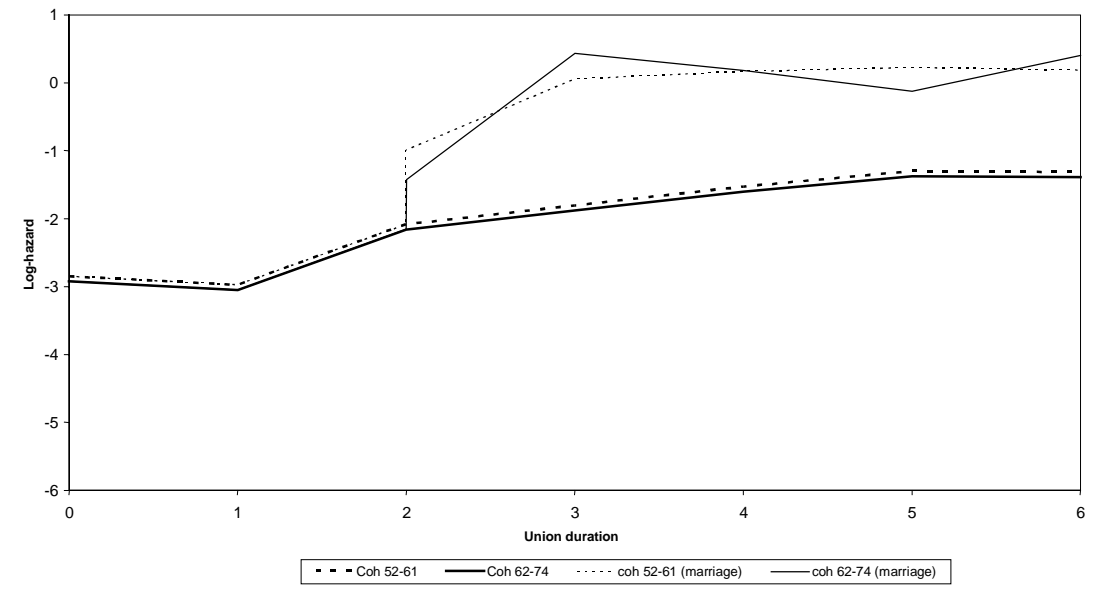


In addition to these two sectors, a third group of women should also be mentioned, that is, women who get married during a pregnancy. Except the order between conception and marriage, this last group appears to have more similarities with women from the "marriage sector" than women from the "cohabiting sector". The comparison between cohorts shows that more and more often, these women remain unmarried during and after the pregnancy of their first child (Note 14). Furthermore, marriage before an eventual pregnancy is less and less frequent, which means that the number of women in the second group of women rose during the observation period.

\section{Conclusions}

Both West Germany and France display a rise in non-marital unions since the beginning of the seventies. During the eighties, France experienced a large increase in non-marital births while this increase was much smaller in West Germany. In both countries, consensual unions were partly recognized by the state, but not in the same way as marriages. The obligation of child recognition and the possibility of parental authority for an unmarried father was introduced in France during the seventies and the eighties. In Germany, this possibility did not happen until 1998. In a broad manner, French policy makers and legislators appear to take into account and respond to new ways of family life. In Germany, legislators more often appear to be defenders of the conjugal family with a male breadwinner. This dissimilarity in family policies and in the social representation of family life until the end of the nineties had several consequences on demographic behaviors, especially on the links between births and marriages.

We assumed that marriage and birth in a consensual union were strongly interrelated in Germany and less in France. Results of event history analyses confirm this hypothesis. The behavior in West Germany appears to be polarized into two sectors. The first sector contains women who get married and have a child. Most of the marriages occur during the pregnancy. The second sector consists of unmarried childless women. Rather than a process of pluralization in family situations, a process of polarization can also be described in the case of France, but it is different from the one in Germany. The first sector consists of women who remain unmarried when they have a child. The second sector contains women who get married before they have a child.

In France, the cohort comparison shows a decrease in the marriage risks before and during the pregnancy: the increase in non-marital births corresponds to an increase in women who belong to the cohabiting sector. In Germany, marriages during the pregnancy or after became more frequent in the youngest cohort. Marriages appear then to be more and more "child-centred marriages" (Nave-Hertz 1989, quoted by Ostner 
2001, p. 95). The German kind of polarization seems to be directly linked with the normative representation of the conjugal family in the family policies, in a sense that this norm induces couples to get married when they wish or plan to have a child. The case of polarization developed in France between a marital sector and a non-marital sector in a context of a more or less pragmatic social representation in family policies seems to correspond to a cleavage in the French society, between "traditional" and "less traditional" couples.

This paper suggests that unobserved heterogeneity plays some role in the polarization of couples in a "cohabiting sector" and a "marital sector" in France and an important role in the polarization in a "family sector" and a "non-family sector" in Germany. Further analyses are required in order to reveal which factors contribute to these processes. The question of research becomes who amongst women or couples are more often in one sector and who is more often in the other sector according to personal characteristics. However, it was not possible to thoroughly address this aspect with the characteristics we used in our analysis.

\section{Acknowledgments}

This research was performed during a stay at the Max Planck Institute for Demographic Research, Rostock, Germany between October 2001 and September 2002. The views expressed in this paper are my own. It does not necessarily reflect the views of the Max Planck Institute for Demographic Research. The author thanks Jan Hoem, Michaela Kreyenfeld, Isabella Locatelli and three anonymous referees for comments on preceding drafts and Jenae Tharaldson for language editing. The author also wishes to thank the Advisory Group of the FFS program of comparative research for its permission, granted under identification number 75 , to use the FFS data on which this study is based.

\section{Notes}

1. We omit respondents who never entered a partnership at the moment of the survey. In the case of the youngest cohort of women (aged between 26 and 30 years), proportions of women who started their first union as a cohabiting union could be exaggerated in the two countries due to censoring which occur earlier than for oldest cohorts. 
2. Results presented here relate to French women (born between 1944 and 1974) and German women (born between 1952 and 1972). A restriction of first partnership to French women born in 1952 or after gives very similar results.

3. We limit our analysis to the first union. Children born after the (eventual) dissolution of the first union are not taken into account. As before, results about the youngest could be a little biased because of censoring (cf. point 2.1.1 and Note 1).

4. The context of cohabiting unions was not the same as today. It corresponded to women who had lost their husbands during the war and formed new partnerships without remarrying in order to keep their status of widow and to keep financial advantages this status gives in the domain of social insurance (Ostner 2001).

5. The context is affected not only by the slight increase in out of-wedlock births in West Germany but moreover by the reunification with East Germany. There were many non-marital births in the new Länder before unification and they continued to increase in the 1990s.

6. This was true until 1996, when taxation allowances linked to lone parenthood were removed for cohabiting couples (Martin and Théry 2001).

7. Translation of "enfant à charge".

8. It should be noted that the shift in the increase in non-marital births during the end of nineties appears to coincide with the new legislation on recognition and parental authority of 1998 in Germany (see Figure 1).

9. Note that a model on the formation of the consensual union will not be estimated here.

10. Numbers of women taken into account are respectively 824 and 1037 . Note that we use normalized weights for our estimations.

11. Note also that the variance of heterogeneity in marriage is low and only significant at the level of $10 \%$.

12. At least, before the conception of the second child.

13. The intercept term which takes into account unobserved heterogeneity, is not significant in the model. It is however higher and significant in the model without heterogeneity (table in appendix). Certainly this can be linked with the fact that the introduction of unobserved heterogeneity has consequences which tend to increase conception rates for a longer union duration, often for those women who get married. 
14. At least, they remain unmarried between the birth of the first child and the conception of the second. 


\section{References}

Baizán Pau, Aassve Arnstein, Billari Francesco (2001). "Cohabitation, marriage, first birth: The interrelationship of family formation events in Spain". MPDIR working Paper, WP-2001-36. Rostock: Max Plank Institute for Demographic Research. http://www.demogr.mpg.de/Papers/Working/WP-2001-036.pdf.

Baizán Pau, Aassve Arnstein, Billari Francesco (2002). "Institutional arrangements and the life course outcomes: The interrelations between cohabitation, marriage and first birth in Germany and Sweden". MPDIR working Paper, WP-2002-26. Rostock: Max Plank Institute for Demographic Research. http://www.demogr.mpg.de/papers/working/wp-2002-026.pdf.

Blossfeld Hans-Peter, Mills Melinda (2001). "A Causal Approach to Interrelated Family events: A Cross-national Comparison of Cohabitation, Nonmarital Conception, and Marriage". Globallife Working papers Series, 14. Bielefeld: Faculty of Sociology, University of Bielefeld.

Blossfeld Hans Peter, Rohwer Goetz (1995). Techniques of Event History Analysis Modelling: New approaches to Causal Analysis. Mahwah-New Jersey: Lawrence Erlbaum associates.

Bradley David (2001). "Regulation of Unmarried Cohabitation in West-European Juridictions. Determinant of Legal Policy". International Journal of Law, Policy and the Family, 15, 1:22-50.

Brien Michael J., Lillard Lee A., Waite Linda J (1999). "Interrelated Family-Building Behaviors: Cohabitation, Marriage and Nonmarital Conception. Demography, 36(4): 535-551.

Council of Europe (2001). Recent demographic developments in Europe. Strasbourg.

Courgeau Daniel, Lelièvre Eva (1989). Analyse démographique des biographies. Paris: INED.

Dienel Christiane (1996). "Politiques familiales en Allemagne: les récents changements", Recherches et Prévisions, 44: 43-51.

Eriksen John, Lindsay Jo (1999). "Unmarried cohabitation and Family Policy: Norway and Australia Compared". Comparative social Research, 18: 79-103.

Fagnani Jeanne (2001). "Les Françaises font toujours plus d'enfant que les Allemandes de l'Ouest - Une esquisse d'interprétation”. Recherches et Prévisions, 64: 49-63. 
Gauthier Anne H. (1996). The State and the Family: A Comparative Analysis of Family Policies in Industrialized Countries. Oxford: Clarendon Press.

Hantrais Linda (1997), "Exploring Relationships between social Policy and Changing Family Forms within the European Union". European Journal of Population, 13: 339-379.

Heeren Henk J. (1982). "Pronatalist Population Policies in some Western European Countries". Population Research and Policy Reviews, 1:137-152.

Huinink Johannes (2001). The macro-micro-link in demography explanations of demographic changes. Bad Herrenhalb: Paper presented at the Euresco conference "The Second Demographic Transition in Europe". http://www.demogr.mpg.de/Papers/workshops/010623_paper08.pdf.

INED (1997). Enquête INED sur les situations familiales et l'emploi (ESFE). Présentation du fichier de l'enquête ESFE et des pondérations. Paris.

Kiernan Kathleen (2001a). "The rise of cohabitation and childbearing outside marriage in Western Europe". International Journal of Law, Policy and the Family. $15,1: 1-21$.

Kiernan Kathleen (2001b). "European Perspectives on Nonmarital Childbearing". In: Wu Lawrence, Wolfe Barbara, editors. Out of Wedlock: Causes and Consequences of Non-marital Fertility. New York: Roussel Sage Foundation, Chapter 3: 77-108.

Kreyenfeld Michaela, Hank Karsten (2000). "Does the availability of child care influence the employment of mothers? Finding from Western Germany". Population Research and Policy Review, 19: 317-337.

Lesthaeghe Ron (1995). "The Second Demographic Transition in Western Countries: An Interpretation". In: Oppenheimer Mason Karen, Jensen An-Magritt, editors. Gender and Family Change in Industrialized Countries. Oxford: Clarendon Press. 17-62.

Lillard Lee A., Panis Constantijn W.A. (2000). aML user's Guide and Reference Manual. Los Angeles: EconWare.

Malpas Nicole, Lambert Pierre-Yves (1993). Europeans and the Family. Results of an opinion survey. Brussels: Commission of the European Communities, DG V. 
Marry Catherine, Kieffer Annick, Brauns Hildegard, Steinmann Susanne (1998). «France-Allemagne: inégales avancées des femmes. Evolution comparée de l'éducation et de l'activité des femmes de 1971 a $1991 »$. Revue française de Sociologie, XXXIX, 2: 353-389.

Martin Claude, Théry Irène (2001). "The PACS and Marriage and Cohabitation in France". International Journal of Law, Policy and the Family. 15, 1: 135-158.

Mazuy Magali, Toulemon Laurent (2001). «Etudes de l'histoire familiale. Premiers résultats de l'enquête en ménages ». Dossiers et Recherches, 93. Paris: INED.

Ostner Ilona (2001). "Cohabitation in Germany - Rules, Reality and Public Discourses". International Journal of Law, Policy and the Family. 15, 1: 88-101.

Pohl Katarina (1995). "Design und Struktur des deutschen FFS". Materialien zur Bevölkerungswissenschaft, 82a, Wiesbaden: Bundesinstitut für Bevölkerungsforschung.

Prioux France (1994). "Le droit et les familles non-mariées en France. Population, 6: 1347-1371.

Schultheis Franz (1993). La Famille : une catégorie du Droit social? Analyse comparative de la prise en compte des situations familiales dans les systèmes de protection sociale en France et en RFA. Kreuzlingen: Rapport de recherche relatif à la convention CNAF-Université de Paris I.

Schultheis Franz (1999). Familien und Politik. Formen Wohlfahrtsstaatlicher Regulierung von Familie im deutsch-französischen Gesellschaftsvergleich. Konstanz: UVK-Univ. Ver. Konstanz.

Stintzing Heike (1999). "Constitutional Values and Social Change. The Case of German Marital and Family Law". International Journal of Law, Policy and the Family, 13: 132-146.

Strohmeier Klaus Peter (1993). "Pluralisierung und Polarisierung der Lebensformen in Deutschland". Aus Politik und Zeitgeschichte, B17:11-22.

Toulemon Laurent (1995). "The Place of Children in the History of Couples". Population: An English Selection, 7:163-186.

Toulemon Laurent (1997). "Cohabitation is here to Stay". Population: An English Selection, 9: 11-46.

Théry Irène (1998). Couples, filiation et parenté aujourd'hui. Paris: Odile Jacob - la Documentation française. 
Demographic Research - Volume 7, Article 18

Vielle Pascale (2001). La sécurité sociale et le coût indirect des responsabilités familiales. Une approche de genre. Bruxelles: Bruylant. 


\section{Appendix}

\section{Results of estimation}

Marriage process

\begin{tabular}{|c|c|c|c|c|c|c|c|c|}
\hline & \multicolumn{4}{|c|}{ Germany } & \multicolumn{4}{|c|}{ France } \\
\hline & \multicolumn{2}{|c|}{ Modele 1} & \multicolumn{2}{|c|}{ Modele2 } & \multicolumn{2}{|c|}{ Modele 1} & \multicolumn{2}{|c|}{ Modele 2} \\
\hline & Estimate & S.E. & Estimate & S.E. & Estimate & S.E. & Estimate & S.E. \\
\hline \multicolumn{9}{|l|}{ Baseline } \\
\hline constant & $-1.8395^{\star \star \star}$ & -0.5303 & $-4.0946^{\star \star \star}$ & -1.0467 & $-2.2117^{\star \star \star}$ & -0.6275 & $-2.3364^{\star \star \star}$ & -0.6745 \\
\hline $0-1$ years & -0.1172 & -0.2412 & $0.9619^{\star \star}$ & -0.3828 & $0.9545^{\star \star \star \star}$ & -0.2325 & $1.0722^{\star \star \star}$ & -0.2578 \\
\hline 1-2 years & $0.4928^{\star \star \star}$ & -0.1832 & $1.1417^{\star \star \star}$ & -0.2586 & -0.2459 & -0.1703 & -0.1358 & -0.1907 \\
\hline $2-4$ years & $-0.2305^{\star \star}$ & -0.1042 & 0.2543 & -0.1577 & $-0.3198^{\star \star \star}$ & -0.1003 & $-0.2577^{\star \star}$ & -0.1128 \\
\hline 4 years and more & -0.0545 & -0.074 & $0.1748^{\star}$ & -0.1012 & -0.0123 & -0.0547 & 0.0209 & -0.0606 \\
\hline \multicolumn{9}{|l|}{ Age } \\
\hline Age 15-19 & 0.0957 & -0.1098 & 0.2167 & -0.1916 & 0.0999 & -0.1346 & 0.1011 & -0.1399 \\
\hline Age 20-24 & -0.0524 & -0.0365 & -0.0701 & -0.0602 & -0.0205 & -0.0363 & -0.0212 & -0.0394 \\
\hline Age 25-29 & $-0.0942^{*}$ & -0.0502 & $-0.1398^{*}$ & -0.0733 & $-0.1231^{\star \star}$ & -0.049 & $-0.1254^{\star \star}$ & -0.0537 \\
\hline Age 30 and more & $-0.3492^{\star}$ & -0.1822 & $-0.4823^{\star \star}$ & -0.2155 & -0.0065 & -0.0731 & -0.0007 & -0.0748 \\
\hline cohorte $62-72 / 74$ & $-0.3122^{\star \star \star}$ & -0.1151 & $-0.516^{\star \star}$ & -0.2156 & -0.1084 & -0.1137 & -0.1457 & -0.1794 \\
\hline \multicolumn{9}{|l|}{ Conception (coh52-61) } \\
\hline 0 to half pregnancy & $5.7564^{\star \star \star}$ & -0.7039 & $6.0371^{\star \star \star}$ & -1.0692 & $4.5263^{\star \star \star}$ & -0.7099 & $4.0582^{\star \star \star}$ & -0.9275 \\
\hline half pregnancy to birth & $-3.9403^{\star \star \star}$ & -1.4428 & $-2.7564^{\star}$ & -1.5629 & $-4.6067^{\star \star \star}$ & -1.1755 & $-4.335^{\star \star \star}$ & -1.2013 \\
\hline birth to one year (1) & $-2.4651^{*}$ & -1.343 & $-3.0403^{\star \star}$ & -1.3867 & $-0.3944^{\star \star}$ & -0.197 & $-0.4347^{\star \star}$ & -0.2 \\
\hline One year and more & 0.0395 & -0.4804 & -0.1151 & -0.4847 & & & & \\
\hline \multicolumn{9}{|l|}{ Conception (coh62-72/74) } \\
\hline 0 to half pregnancy & $6.4266^{\star \star \star}$ & -0.675 & $6.6745^{\star \star \star}$ & -1.1347 & $5.3353^{* * *}$ & -0.6485 & $4.8728^{\star \star \star}$ & -0.8796 \\
\hline half pregnancy to birth & $-2.6303^{\star \star}$ & -1.1574 & -0.7813 & -1.2696 & $-6.2794^{\star \star \star}$ & -1.8662 & $-6.1757^{\star \star \star}$ & -1.9038 \\
\hline birth to one year (1) & $-1.0988^{*}$ & -0.6589 & $-1.2545^{\star}$ & -0.7049 & -0.2375 & -0.6519 & -0.2783 & -0.66 \\
\hline One year and more & -0.234 & -0.6294 & -0.4031 & -0.6779 & & & & \\
\hline \multicolumn{9}{|l|}{ Background } \\
\hline Parent divorced & 0.1548 & -0.1546 & 0.145 & -0.3103 & -0.2901 & -0.2409 & -0.3284 & -0.2729 \\
\hline Second union or more & -0.0617 & -0.2055 & $0.9459^{\star \star}$ & -0.3945 & $-0.37^{\star}$ & -0.1923 & -0.2515 & -0.23 \\
\hline Level 1 education & 0.1764 & -0.124 & $0.6455^{\star \star \star}$ & -0.2499 & -0.2338 & -0.1426 & $-0.2706^{*}$ & -0.1596 \\
\hline Level 3 education & 0.1649 & -0.2778 & -0.0165 & -0.5359 & 0.117 & -0.1176 & 0.0702 & -0.1362 \\
\hline enrolled in education & $-0.7516^{\star \star \star}$ & -0.1767 & $-1.2859^{\star \star \star}$ & -0.3262 & $-0.898^{\star * \star}$ & -0.228 & $-0.9387^{\star \star \star}$ & -0.2387 \\
\hline
\end{tabular}

(1) Only after birth in case of France

Significance: ${ }^{*}=10 \% ;{ }^{* *}=5 \% ;{ }^{* \star *}=1 \%$ 


\section{Results of estimation (continued)}

First conception process

\begin{tabular}{|c|c|c|c|c|c|c|c|c|}
\hline & \multicolumn{4}{|c|}{ Germany } & \multicolumn{4}{|c|}{ France } \\
\hline & \multicolumn{2}{|c|}{ Modele 1} & \multicolumn{2}{|c|}{ Modele2 } & \multicolumn{2}{|c|}{ Modele 1} & \multicolumn{2}{|c|}{ Modele 2} \\
\hline & Estimate & S.E. & Estimate & S.E. & Estimate & S.E. & Estimate & S.E. \\
\hline \multicolumn{9}{|l|}{ Baseline } \\
\hline constant & -1.5593 ** & -0.61 & 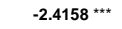 & -0.8306 & -0.7914 & -0.4993 & $-1.3213^{*}$ & -0.7864 \\
\hline $0-1$ years & 0.2348 & -0.298 & 0.5192 & -0.3369 & $-0.7293^{* * \star}$ & -0.2649 & -0.2594 & -0.3752 \\
\hline $1-2$ years & -0.2445 & -0.2215 & -0.0408 & -0.2456 & $0.5103^{* *}$ & -0.1993 & $0.7573^{* \star *}$ & -0.2429 \\
\hline $2-4$ years & 0.0729 & -0.105 & $0.2809 * *$ & -0.1365 & -0.1116 & -0.0912 & 0.1446 & -0.1417 \\
\hline 4 years and more & -0.0897 & -0.0614 & 0.0152 & -0.0807 & -0.0212 & -0.0453 & 0.0936 & -0.0689 \\
\hline \multicolumn{9}{|l|}{ Age } \\
\hline Age 15-19 & -0.2104 * & -0.1249 & -0.1573 & -0.1435 & $-0.1971 *$ & -0.1103 & $-0.3055^{* *}$ & -0.1445 \\
\hline Age 20-24 & 0.0379 & -0.0416 & 0.0395 & -0.0474 & -0.0146 & -0.0345 & -0.0093 & -0.0482 \\
\hline Age 25-29 & 0.0609 & -0.0417 & 0.0751 & -0.0529 & $0.0871^{* *}$ & -0.0376 & 0.1338 ** & -0.0577 \\
\hline Age 30 and more & $-0.3304 * * \star$ & -0.1057 & $-0.3778 * * *$ & -0.1131 & -0.0988 & -0.0708 & -0.1083 & -0.0875 \\
\hline cohorte $62-72 / 74$ & -0.0015 & -0.1252 & -0.0319 & -0.1564 & $-0.5824^{* \star *}$ & -0.1021 & $-0.6577^{\star * *}$ & -0.1319 \\
\hline \multicolumn{9}{|l|}{ Marriage (cohorte 52-62) } \\
\hline Intercept & 0.7268 ** & -0.3293 & 0.2935 & -0.3811 & $1.2031^{\star \star \star}$ & -0.2518 & $1.0935^{\star \star \star}$ & -0.3116 \\
\hline Marriage to on year & 0.194 & -0.4498 & 0.157 & -0.4698 & 0.2489 & -0.3291 & $0.7688^{*}$ & -0.4443 \\
\hline One to three years & 0.2429 & -0.1562 & 0.3336 & -0.2051 & $-0.3128^{\star *}$ & -0.1486 & -0.1687 & -0.1973 \\
\hline Three years and more & -0.2289 ** & -0.0901 & $-0.2613^{\star *}$ & -0.1069 & -0.0459 & -0.101 & -0.0265 & -0.1191 \\
\hline \multicolumn{9}{|c|}{ Marriage (cohorte 62-72/74) } \\
\hline Intercept & $0.9726^{* \star *}$ & -0.3541 & 0.4696 & -0.4019 & $0.9155^{* \star *}$ & -0.2658 & 0.7319 ** & -0.3248 \\
\hline Marriage to on year & 0.2507 & -0.4932 & 0.3924 & -0.5327 & $1.0231^{\star \star \star}$ & -0.353 & $1.5807^{\star \star \star}$ & -0.4795 \\
\hline One to three years & -0.5192 * & -0.2662 & -0.6241 ** & -0.2861 & $-0.6701^{* * *}$ & -0.2146 & -0.5309 ** & -0.2631 \\
\hline Three years and more & 0.0939 & -0.2326 & 0.0588 & -0.2445 & $0.4024^{\star \star}$ & -0.1652 & 0.5423 ** & -0.2256 \\
\hline \multicolumn{9}{|l|}{ Background } \\
\hline Parent divorced & 0.2429 & -0.1538 & 0.3083 & -0.2144 & $0.5425^{* * *}$ & -0.1951 & 0.7381 ** & -0.3489 \\
\hline Second union or more & 0.3631 ** & -0.1715 & $0.9013^{* * *}$ & -0.3145 & -0.0519 & -0.1602 & $0.537^{*}$ & -0.3237 \\
\hline Level 1 education & $0.5238^{* * *}$ & -0.1213 & $0.8618^{* * *}$ & -0.2273 & 0.2609 ** & -0.1046 & $0.6074^{* * *}$ & -0.2102 \\
\hline Level 3 education & 0.4068 ** & -0.2021 & 0.4124 & -0.2661 & -0.189 & -0.1364 & -0.5486 ** & -0.2547 \\
\hline enrolled in education & $-0.977^{* * *}$ & -0.2187 & $-1.1941^{* \star \star}$ & -0.2924 & $-0.9999^{* * *}$ & -0.2822 & $-1.2708^{* * *}$ & -0.3887 \\
\hline
\end{tabular}

Significance: ${ }^{*}=10 \% ;{ }^{* \star}=5 \% ;{ }^{* \star \star}=1 \%$ 


\section{Results of estimation (continued)}

Standard deviations and correlation

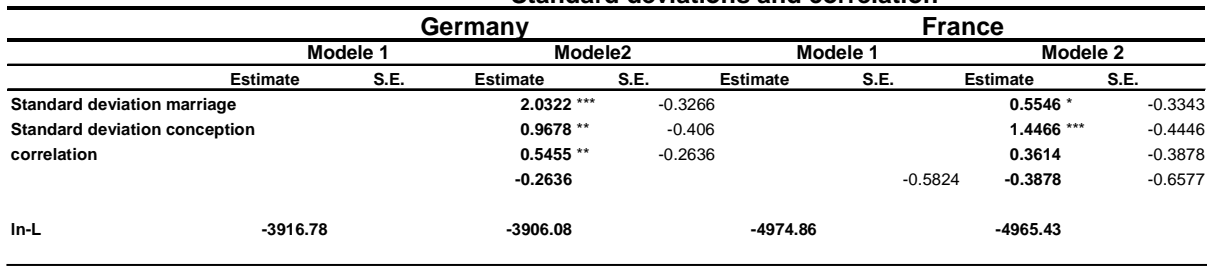

Significance : ${ }^{*}=10 \% ;{ }^{* *}=5 \% ;{ }^{* *}=1 \%$ 
Demographic Research - Volume 7, Article 18

http://www.demographic-research.org 